\title{
Antiradical activity, total phenolic, and total flavonoids extract and fractions of pumpkin (Cucurbita moshata Duch) leaves
}

\author{
Sabarudin, Ruslin, Zubaydah, W.O.S. Sartinah, A. Buton, S. and *Yamin \\ Pharmacy of Departement of Halu Oleo University, Kendari City, Indonesia
}

\begin{abstract}
Article history:
Received: 24 September 2020

Received in revised form: 29

October 2020

Accepted: 1 January 2021

Available Online: 18 April

2021
\end{abstract}

Keywords:

Antiradical,

Cucurbita moschata,

DPPH (2,2-diphenyl-1-

picryhidrazyl),

Flavonoid total,

Phenolic total

DOI:

https://doi.org/10.26656/fr.2017.5(2).529

\begin{abstract}
Pumpkin (Cucurbita moshata Duch) is one of the Cucurbitaceae plants, which traditionally used to treat skin diseases, measles, jaundice, insomnia, cancer and enhances endurance. Therefore, it was necessary to explore the potential of pumpkin leaves as antiradical. This research aim was to examine the antiradical activity and total phenolic and total flavonoids of pumpkin leaves extract and its fractions using the DPPH method and determined the phenolic and flavonoid contents. Pumpkin leave powder was extracted with methanol. Furthermore, water was added into methanol extract, and be partitioned using n-hexane and ethyl acetate to obtain n-hexane, ethyl acetate, and water fractions. The antiradical activities of pumpkin leave extract and fractions were determined using DPPH (2,2-diphenyl-1-picryhidrazyl) method. Ethyl acetate fraction obtained higher antiradical activities $\left(\mathrm{IC}_{50} 6.737 \pm 0.196 \mu \mathrm{g} / \mathrm{mL}\right)$. Correlation of total phenolic and flavonoid contents to inhibit DPPH radical showed that phenolic and flavonoid contents on pumpkin leaves could be inhibited DPPH radical $\mathrm{R}^{2}=0.8994$ and $\mathrm{R}^{2}=0.9061$, respectively. Extracts and fraction pumpkin leaves show strong antiradical activity with DPPH methods, so their potential as antiradical can developed and can be used as a functional food.
\end{abstract}

\section{Introduction}

Since ancient times, plants and their metabolites have been used as medicine. Natural source of antioxidant from Traditional medicine is widely used, which these antioxidant substances may help to develop new potential drug (Bag and Devi, 2015). Antioxidants are defined as a compound that delays or prevents oxidation of biomolecules such as lipid, protein, and DNA, by counteracting free radicals from these biomolecules which prevent cell damage (Proestos et al., 2013; Labiad et al., 2017). In the last several decades, many researchers have traced the antioxidant activity of plants. Where, it is believed that the use of natural antioxidants will reduce the chance of degenerative diseases, such as cardiovascular disease and cancer (Elkhamlichi et al., 2017).

Pumpkin (Cucurbita moschata) is a plant of the family Cucurbitaceae which is widely distributed in tropical, subtropical, temperate, and hot regions (AlQaisy and Rathi, 2020). Traditionally, pumpkin ( $C$. moshata) is used to treat skin diseases, measles, jaundice, insomnia, cancer, and can help to enhance endurance. While pumpkin seed oil can be used in hypertension, arthritis, hypercholesterolemia, bladder disorders, and urethral pressure treatment (Suresh and Sisodia, 2018). Phytochemical screening shows flesh and pumpkin seeds containing flavonoids, terpenoids, saponins, and tannins (Marbun et al., 2018).

The objective of the research was to determine the potential antiradical and phenolic and flavonoids total of pumpkin extracts and fractions leaves

\section{Materials and methods}

\subsection{Materials}

Pumpkin leaves were obtained from Padala'a Village, Kepulauan Menui District, Moruali Regency, Central Sulawesi Province, DPPH (2,2-diphenyl-1picryhidrazyl) (Sigma-Aldrich ${ }^{\circledR}$, USA), Gallic Acid (Sigma-Aldrich $^{\circledR}$, USA), Quercetin (Sigma-Aldrich ${ }^{\circledR}$, USA), methanol (E. Merck, Germany), ethyl acetate, nhexane, and aquadest.

\subsection{Extraction}

Pumpkin leaves were dried in the sun and covered with black cloth. Then, the dried leaves were powdered. Pumpkin leaf powder $(30 \mathrm{~g})$ was macerated with 
methanol for $3 \times 24 \mathrm{hrs}$, where every $24 \mathrm{hrs}$ the mixture was filtered, and the solvent was replaced. The extract was evaporated to dryness using Rotary Evaporator. Water (1 L) was added into methanol extract $(40 \mathrm{~g})$, then the extract was fractionated with n-hexane and ethyl acetate to obtain the n-hexane, ethyl acetate, and water fraction, as shown in Figure 1.

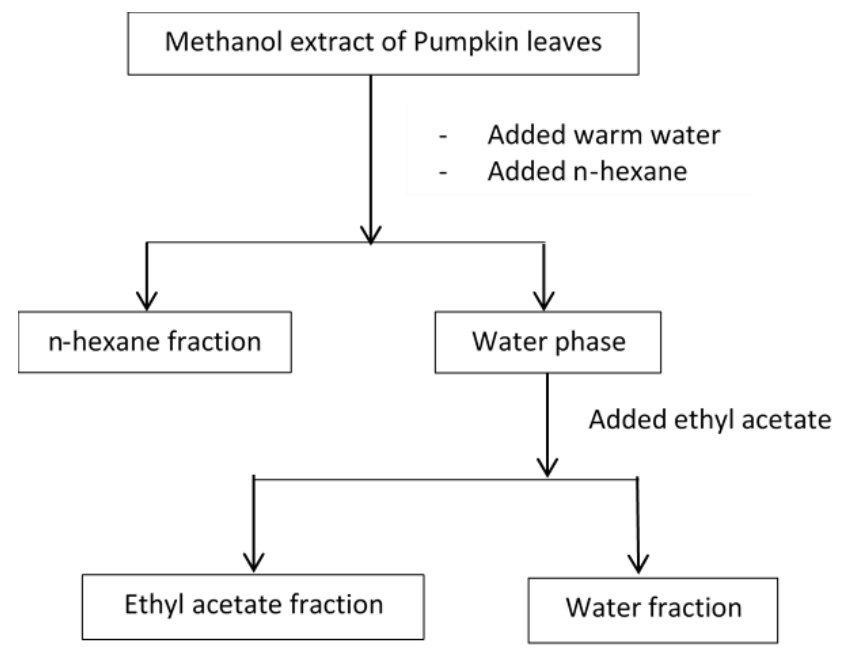

Figure 1. Schematic fractionation of pumpkin leaves methanol extract

\subsubsection{Yield extract}

The yield extract that has been obtained is calculating using Equation 1 (Nurmala and Novianti, 2020)

$$
\text { yield extract }=\frac{\text { weight of extract obtained }}{\text { weight of simplicia }} \times 100 \%
$$

\subsubsection{Yield fraction}

The yield fraction that has been obtained is calculating using Equation 2

$$
\text { yield fraction }=\frac{\text { weight of fraction }}{\text { weight of extract }} \times 100 \%
$$

\subsection{Phytochemical screening}

Phytochemical screening was conducted to determine the profile of secondary metabolites in langsat seeds extracts and fractions. Phytochemical screening methods based on (Yamin et al., 2020).

\subsubsection{Alkaloids}

The extract and fractions of Lansium domesticum Coor seeds were inserted separately into $1 \mathrm{~mL}$ test tubes and added with three drops of Dragendorff's reagent. The formation of brown precipitate indicated the presence of alkaloid.

\subsubsection{Flavonoids}

The extract and fractions of Lansium domesticum
Coor seeds were inserted separately into test $1 \mathrm{~mL}$ tubes and added with $0.2 \mathrm{~g}$ of magnesium powder and $2 \mathrm{~mL}$ of concentrated $\mathrm{HCl}$. The formation of red, orange and green solutions indicated the flavonoid presence.

\subsubsection{Tannin}

The extract and fractions of Lansium domesticum Coor seeds were inserted separately into $1 \mathrm{~mL}$ test tubes and added with $1 \mathrm{~mL}$ of $1 \% \mathrm{Fe}$ (III) chloride solution. The formation of blue to black solution indicated the presence of tannin.

\subsubsection{Terpenoid}

The extract and fractions of Lansium domesticum Coor seeds were inserted separately into $1 \mathrm{~mL}$ test tubes and added with $0.5 \mathrm{~mL}$ of acetic acid anhydride and 2 $\mathrm{mL}$ of concentrated sulfuric acid. The formation of green, bluish, and brown solutions indicated the terpenoid presence.

\subsubsection{Saponin}

The extract and fractions of Lansium domesticum Coor seeds were inserted separately into $1 \mathrm{~mL}$ test tubes and added with $2 \mathrm{~mL}$ of hot water, then cooled and shaken for $10 \mathrm{~s}$. It was declared positive for saponin if the fume generated stabilized in less than 10 mins.

\subsection{Determination of antiradical activity with DPPH method}

The determination of radical activity was done by following the Garcia method (Garcia et al., 2012) which modified the number of samples to use. Methanol p.a (3 $\mathrm{mL}$ ) and $1 \mathrm{~mL}$ of DPPH radical (2,2-diphenyl-1picryhidrazyl) was added to the sample $(1 \mathrm{~mL})$. The mixture was shaken until homogeneous, then incubated in a dark room for 30 mins. Then the absorbance of the sample was measured using a UV-Vis spectrophotometer at a wavelength of $513 \mathrm{~nm}$. The antioxidant activity of extract and its fractions to inhibit DPPH radicals can be calculated using the following equation:

$$
\% \text { inhibition }=\frac{A_{c}-A_{s}}{A_{c}} \times 100 \%
$$

Where $\%$ inhibition $=$ percentage of DPPH radical inhibition, $\mathrm{Ac}=$ Absorbance of control and $\mathrm{As}=$ Concentration of sample

The value of antioxidant strength $\left(\mathrm{IC}_{50}\right)$ was calculated based on the linear regression equation between $\%$ inhibition with the concentration of sample or fractions, where the $x$-axis was the concentration while the $y$-axis was $\%$ inhibition. The regression equation $y=$ $\mathrm{bx}+\mathrm{a}$. Then, the y value was replaced by 50 . Where $\mathrm{IC}_{50}$ was defined as the concentration of the sample needed to 
inhibit 50\% of DPPH radicals (Rohman et al., 2017).

\subsection{Determination of total phenolic content}

Determination of total phenolic content of pumpkin leaves extracts and fractions using the modifying FolinCiocalteau method according to John et al. (2014). Each concentration series of the sample ( $1 \mathrm{~mL}$, respectively) were taken and added $0.4 \mathrm{~mL}$ of the Folin-Ciocalteau reagent, then shaken. After 8 mins later, added $4 \mathrm{~mL}$ of $7 \% \mathrm{Na}_{2} \mathrm{CO}_{3}$ and shaken until homogeneous then sufficient with up to $10 \mathrm{~mL}$ volume, allowed to stand for 30 mins and then absorbed by using UV-Vis spectrophotometry at a wavelength of $750 \mathrm{~nm}$. The measurement of each sample concentration series was carried out three times for replication. Total phenolic levels are expressed as Gallic Acid Equivalents (GAE).

\subsection{Determination of total flavonoid content}

Measurement of total flavonoid levels was carried out using the colorimeter method (John et al., 2014; Vyas et al., 2015) by modifying, $10 \mathrm{mg}$ of sample dissolved with methanol p.a. $10 \mathrm{~mL}$. Then, $1 \mathrm{~mL}$ was taken with $3 \mathrm{~mL}$ of methanol p.a., then $0.2 \mathrm{~mL}$ of $10 \%$ aluminum chloride and $0.2 \mathrm{~mL}$ of potassium acetate $1 \mathrm{M}$ were added and the volume of $10 \mathrm{~mL}$ was sufficient with distilled water. The mixture was incubated for 30 mins. Then the absorbance was measured using a UV-Vis spectrophotometer at $435 \mathrm{~nm}$ wavelength. Total flavonoid levels are expressed as Quercetin Equivalent (QE).

\section{Results and discussion}

In this study, the extraction method used was maceration, then followed by fractionation using solvents with different polarities. The purpose of using solvents with different polarities was to extract completely compounds whether non-polar, semipolar, and polar. The same compound can be found in different solvents, but the levels are different in each solvent. This depends on the distribution coefficient of the compound (Yamin et al., 2010). The results of pumpkin leave extraction and fractionation are presented in Table 1.

Table 1. Pumpkin leave extraction and fractionation results

\begin{tabular}{ccccc}
\hline No. & Solvents & $\begin{array}{c}\text { Sample weight } \\
(\mathrm{g})\end{array}$ & $\begin{array}{c}\text { Extract/fractions } \\
\text { weigh }(\mathrm{g})\end{array}$ & $\begin{array}{c}\text { Yield } \\
(\%)\end{array}$ \\
\hline 1 & Methanol & 350 & 89.2 & 25.57 \\
2 & N-hexane & 40 & 8.2 & 20.5 \\
3 & Ethyl acetate & 40 & 16.4 & 40 \\
4 & Water & 40 & 15.4 & 38.5 \\
\hline
\end{tabular}

Based on the data in Table 1 shows that the crude extract yield is $25.57 \%$. This result indicates that the pumpkin leaves can be utilized. Even after fractionation, the ethyl acetate fraction shows the highest yield of $40 \%$, which means that the compounds in pumpkin leaves are mostly semi-polar. The compound will be easily attracted to a suitable solvent, according to the principle of "like dissolved like", where compounds will be attracted to solvents with the same polarity (Amaro et al., 2015).

Phytochemistry screening showed the extract and fraction of pumpkin leaves contained secondary metabolite alkaloids, flavonoids, tannin, saponin and terpenoids. The result of phytochemistry screening shown in Table 2.

Table 2. Phytochemical screening extract and fractions of pumpkin leaves

\begin{tabular}{ccccc}
\hline \multirow{2}{*}{ Testing } & \multicolumn{5}{c}{ Sample } \\
\cline { 2 - 5 } & $\begin{array}{c}\text { Methanol } \\
\text { extract }\end{array}$ & $\begin{array}{c}\text { n-hexane } \\
\text { fraction }\end{array}$ & $\begin{array}{c}\text { Ethyl acetate } \\
\text { fraction }\end{array}$ & $\begin{array}{c}\text { Water } \\
\text { fraction }\end{array}$ \\
\hline Flavonoid & + & + & + & + \\
Alkaloid & + & + & + & + \\
Tannin & + & + & + & + \\
Terpenoid & + & + & + & + \\
Saponin & + & + & + & + \\
\hline
\end{tabular}

Utilization radical DPPH (2,2-diphenyl-1picryhidrazyl) in determining the strength of free radical caused by DPPH is a stable radical (Shekhar and Anju, 2014), which receives electrons or hydrogen radical to become a stable diamagnetic molecule (Arina and Rohman, 2013). Besides, DPPH radicals are also considered a standard colorimetric technique to measure the antioxidant activity of extracts and pure compounds from plants (Mishra et al., 2012). The reduction ability of DPPH free radicals is based on a decrease in wavelength at $513 \mathrm{~nm}$ after adding antioxidants. In this study, the standard used is vitamin $\mathrm{C}$ and solvent for dissolving DPPH using methanol. The use of methanol is based on its sensitivity compared to other solvents (Rohman et al., 2017).

The antiradical activity was determined using vitamin $\mathrm{C}$ as a positive control. The result in Table 3 , shows the $\mathrm{IC}_{50}$ values of pumpkin leave extracts and fractions with vitamin $\mathrm{C}$ as positive controls. Pumpkin leave extract and fractions showed antiradical activity based on the $\mathrm{IC}_{50}$ value. The smaller $\mathrm{IC}_{50}$ value of the sample indicates that the stronger functions as an antiradical. Based on the data in Table 3 ethyl acetate fraction is the most powerful fraction as antiradical. This is in line with different research which the ethyl acetate fraction of the red fruit (Panandus conoideus L.) (Rohman et al., 2010), senggani leaves (Melastoma candidum D. Don) (Marjoni and Zulfisa, 2017), 
rambutan peel (Rohman et al., 2017). Figure 2 shows the correlation of ethyl acetate fraction inhibition with the amount of DPPH radical, ethyl acetate fraction can be further separated to obtain an active isolate.

Table $3 . \mathrm{IC}_{50}$ values extract and fractions of pumpkin leaves

\begin{tabular}{cc}
\hline Sample & $\mathrm{IC}_{50}$ value $(\mu \mathrm{g} / \mathrm{mL})$ \\
\hline Methanol extract & $8.832 \pm 1.429$ \\
Ethyl acetate fraction & $6.7371 \pm 0.1959$ \\
N-hexane fraction & $9.6789 \pm 0.5427$ \\
Water fraction & $11.8052 \pm 0.63$ \\
Vitamin C & $4.2454 \pm 0.0293$ \\
\hline
\end{tabular}

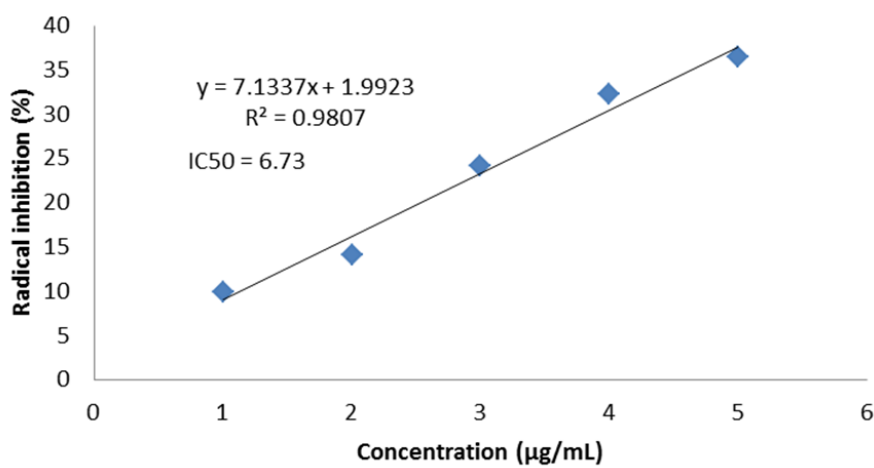

Figure 2. Correlation between the concentration of ethyl acetate fraction $(\mu \mathrm{g} / \mathrm{mL})$ with radical inhibition (\%)

Phenolic and flavonoid compounds are known to have antiradical activity. These compounds can donate hydrogen radicals contained in the hydroxy group $(-\mathrm{OH})$ to attached in radical DPPH, hence the DPPH radical becomes stable (Pietta, 2000; Heim et al., 2002; Agati et al., 2012). Therefore, some antioxidant activity of natural substances associated with phenolic compounds and flavonoids (Rohman et al., 2017)

Phenolic and flavonoids are the most abundant compounds in plants that are beneficial in human health (Wijaya et al., 2017). Total phenolic and flavonoid levels have a correlation with antioxidant power in extracts and fractions (Nur et al., 2019). Table 4 and Table 5 shows the total phenolic and flavonoid content of pumpkin leaf extracts and fractions. The ethyl acetate fraction obtained high phenolic and flavonoid levels compared to methanol extract, n-hexane, and water fractions. Phenolic and flavonoid levels of ethyl acetate fraction were $56.43 \mathrm{~g} \mathrm{GEA} / 100 \mathrm{~g}$ sample and $55.07 \mathrm{~g} \mathrm{QE} / 100 \mathrm{~g}$ sample, respectively. These results indicated that the value of antioxidant strength correlates with phenolic and flavonoid levels contained in the extract and fraction of pumpkin leaves.

The correlation between antiradical strength $\left(\mathrm{IC}_{50}\right)$ with phenolic and flavonoid levels of extracts and pumpkin leaf fraction is shown in Figure 3. The correlation coefficient $\left(\mathrm{R}^{2}\right)$ is used to determine the

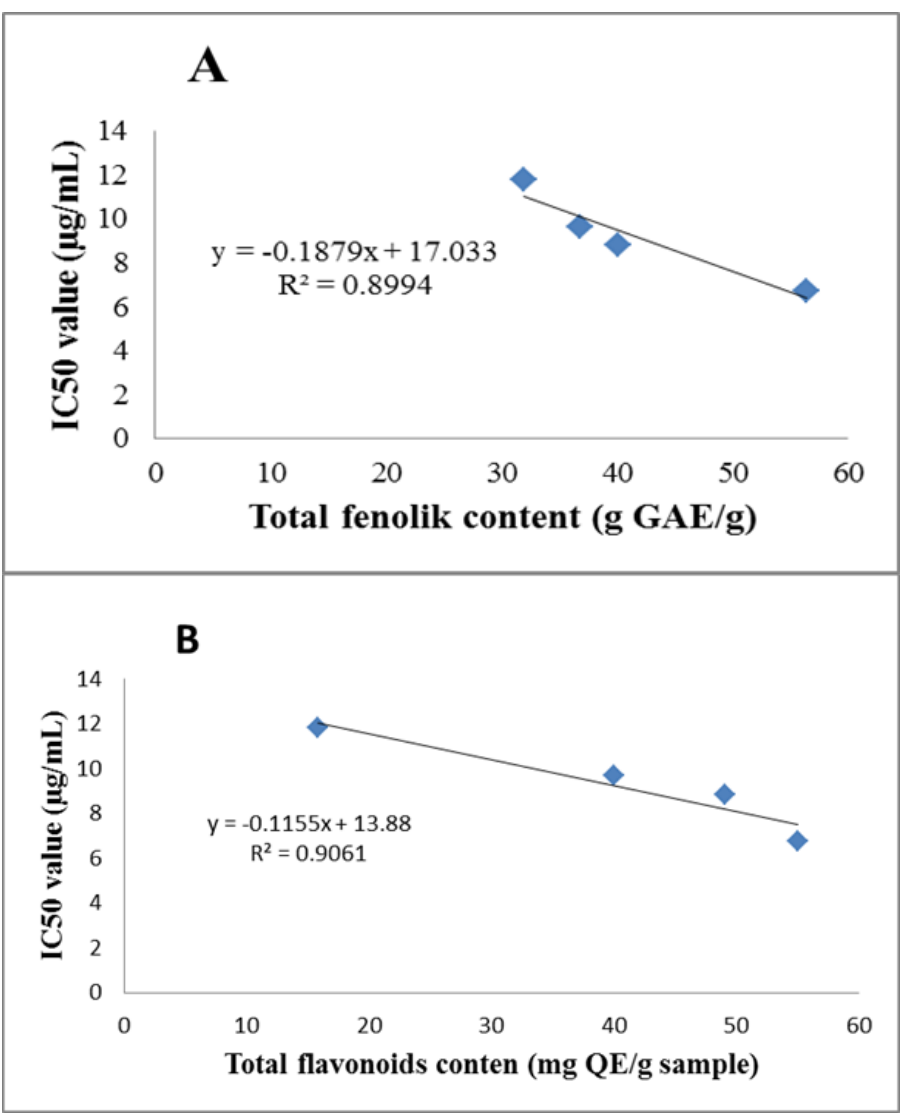

Figure 3. Correlation between total phenolic content $(\mathrm{A})$ and total flavonoid content $(\mathrm{B})$ ( $\mathrm{x}$-abscissa) with $\mathrm{IC}_{50}$ value $(\mathrm{y}-$ ordinate) of pumpkin leaves extract and fractions

Table 4. Total phenolic content in pumpkin leaves extract and fractions

\begin{tabular}{ccccc}
\hline Sample & $\begin{array}{c}\text { Linear regression of } \\
\text { Gallic Acid }\end{array}$ & $\begin{array}{c}\text { Correlation } \\
\text { coefficient }\end{array}$ & $\begin{array}{c}\text { Average } \\
\text { absorbance }\end{array}$ & $\begin{array}{c}\text { Phenolic value } \\
\text { (g GEA/100g sample) }\end{array}$ \\
\hline Methanol extract & & & 0.615 & 40.14 \\
Ethyl acetate fraction & $\mathrm{y}=0.007 \mathrm{x}+0.334$ & $\mathrm{R}^{2}=0.9874$ & 0.729 & 56.43 \\
N-hexane fraction & & & 0.592 & 36.86 \\
Water fraction & & & 0.558 & 32 \\
\hline
\end{tabular}

Table 5. Total flavonoid content in pumpkin leaves extract and fractions

\begin{tabular}{ccccc}
\hline Sample & $\begin{array}{c}\text { Linear regression of } \\
\text { quercetin }\end{array}$ & $\begin{array}{c}\text { Correlation } \\
\text { coefficient }\end{array}$ & $\begin{array}{c}\text { Average } \\
\text { absorbance }\end{array}$ & $\begin{array}{c}\text { Flavonoid value } \\
(\mathrm{g} \text { QE/100g sample) }\end{array}$ \\
\hline Methanol extract & & & 0.506 & 49.11 \\
Ethyl acetate fraction & $\mathrm{y}=0.0057 \mathrm{x}+0.2261$ & $\mathrm{R}^{2}=0.9612$ & 0.54 & 55.07 \\
N-hexane fraction & & & 0.454 & 39.98 \\
Water fraction & & & 0.316 & 15.77 \\
\hline
\end{tabular}


effect of phenolic and flavonoid content on antiradical strength. Figure 3 shows the correlation between $\mathrm{IC}_{50}$ values with total phenolic content and flavonoids. Absis (x) is the $\mathrm{IC}_{50}$ value and ordinate (y) is the phenolic and flavonoid content of the methanol extract and its fractions. The $\mathrm{R}^{2}$ value obtained is 0.8994 and 0.9061 . This indicates that $89.94 \%$ of antiradical strength is influenced by phenolic content and $90.61 \%$ is influenced by flavonoid content contained in pumpkin leave extract and fraction.

\section{Conclusion}

Pumpkin leaves have antiradical abilities, which the ethyl acetate fraction exhibits the strongest antiradical. The correlation between total phenolic, flavonoid content, and radicals inhibition is very high. These show the compounds most responsible as antiradical are phenolic and flavonoid compounds. Thus, pumpkin leaves can be developed as a functional food.

\section{Conflict of interest}

The authors declare no conflict of interest.

\section{Acknowledgments}

Chancellor of the Universitas Halu Oleo who has provided research grants through schema Penelitian Dasar through the LPPM Universitas Halu Oleo.

\section{References}

Agati, G., Azzarello, E., Pollastri, S. and Tattini, M. (2012). Flavonoids as antioxidants in plants: Location and functional significance. Plant Science, 196, 67-76. https://doi.org/10.1016/ j.plantsci.2012.07.014

Al-Qaisy, M.R. and Rathi, D.M.H. (2020). Total Phenolic Content and Antioxidant Efficacy Of Three Parts Of The Pumpkin Cucurbita moschata and the Effect of the Drying Method on them. World Journal Of Pharmacy and Pharmaceutical Sciences, 8(4), 1679-1689. https://doi.org/10.20959/wjpps2019413561

Amaro, H.M., Andrade, P.B., Malcata, F.X., Guedes, A.C., Jorge, R.D., Ferreira, V., Frias, R., Process, E.and Frias, R. (2015). Effect of Solvent System on Extractability of Lipidic Components of Scenedesmus obliquus (M2-1) and Gloeothece sp. on Antioxidant Scavenging Capacity Thereof. Marine Drugs, 13(10), 6453-6471. https://doi.org/10.3390/ md13106453

Arina, N.B. and Rohman, A. (2013). The phenolic contents and antiradical activity of Indonesian.
International Food Research Journal, 20(3), 11191124.

Bag, G.C. and Devi, P.G. (2015). Research Article Assessment of Total Flavonoid Content and Antioxidant Activity of Methanolic Rhizome Extract of Three Hedychium Species of Manipur Valley 1. International Journal of Pharmaceutical Sciences Review and Research, 30(28), 154-159.

Elkhamlichi, A., Hajaji, H.E., Faraj, H., Alami, A., Bali, B.E. and Lachkar, M. (2017). Phytochemical screening and evaluation of antioxidant and antibacterial activities of seeds and pods extracts of Calycotome villosa subsp. Intermedia, 7(4), 192198. https://doi.org/10.7324/JAPS.2017.70428

Garcia, E.J., Alencar, S.M.D., Reis, A., Loguercio, A.D., Helena, R. and Grande, M. (2012). Antioxidant Activity by DPPH Assay of Potential Solutions to be Applied on Bleached Teeth. Brazilian Dental Journal, 23, 22-27. https://doi.org/10.1590/S010364402012000100004

Heim, K.E., Tagliaferro, A.R. and Bobilya, D.J. (2002). Flavonoid antioxidants: chemistry, metabolism Flavonoid antioxidants : chemistry, metabolism and structure-activity relationships. The Journal of Nutritional Biochemistry, 13(10), 572-584. https:// doi.org/10.1016/S0955-2863(02)00208-5

John, B., Sulaiman, C.T., George, S. and Reddy, V.R.K. (2014). Total Phenolics and Flavonoids in Selected Medicinal Plants From Kerala. International Journal of Pharmacy and Pharmaceutical Sciences, 6(1), 406-408.

Labiad, M.H., Harhar, H., Ghanimi, A. and Tabyaoui, M. (2017). Phytochemical Screening and Antioxidant Activity of Moroccan Thymus satureioïdes Extracts. Journal of Materials and Environmental Sciences, 8 (6), 2132-2139

Marbun, N., Sitorus, P. and Sinaga, S.M. (2018). Antidiabetic Effects of Pumpkin (Cucurbita Moschata Durch) Flesh and Seeds Extracts in Streptozotocin Induced Mice. Asian Journal of Pharmaceutical and Clinical Research, 11(2), 91-93. https://doi.org/10.22159/ajpcr.2018.v11i2.22023

Marjoni, M. and Zulfisa, A. (2017). Antioxidant Activity of Methanol Extract/Fractions of Senggani Leaves (Melastoma candidum D. Don). Pharmaceutica Analytica Acta, 8, 557. https://doi.org/10.4172/21532435.1000557

Mishra, K., Ojha, H. and Chaudhury, N.K. (2012). Estimation of antiradical properties of antioxidants using DPPH assay: Critical review and results Estimation of antiradical properties of antioxidants using DPPH $\AA$ assay: A critical review and results. 
Food Chemistry, 130(4), 1036-1043. https:// doi.org/10.1016/j.foodchem.2011.07.127

Nur, S., Mubarak, F., Jannah, C., Winarni, D.A., Rahman, D.A., Hamdayani, L.A. and Sami, F.J. (2019). Total phenolic and flavonoid compounds, antioxidant and toxicity profile of extract and fractions of paku atai tuber (Angiopteris ferox Copel). Food Research, 3(6), 734-740. https:// doi.org/10.26656/fr.2017.3(6).135

Nurmala, S. and Novianti, S. (2020). The Effectiveness of the Antiinfamation Combination Gel of Okra Fruit (Abelmoschus esculentus) Extracts and Shallots Extract (Allium cepa L.). Journal of Tropical Pharmacy and Chemistry, 5(1), 1-8. https:// doi.org/10.25026/jtpc.v5i1.228

Pietta, P. (2000). Flavonoids as Antioxidants. Journal of Natural Products, 63, 1035-1042. https:// doi.org/10.1021/np9904509

Proestos, C., Lytoudi, K., Mavromelanidou, O.K., Zoumpoulakis, P. and Sinanoglou, V.J. (2013). Antioxidant Capacity of Selected Plant Extracts and Their Essential Oils. Antioxidants, 2, 11-22. https:// doi.org/10.3390/antiox2010011

Rohman, A., Riyanto, S., Mistriyani, Shuhaira and Nugroho, A.E. (2017). Antiradical Activities of Rambutan Peel: Study from Two Cultivars. Research Journal of Phytochemistry, 11(1), 42-47. https:// doi.org/10.3923/rjphyto.2017.42.47

Rohman, A., Riyanto, S., Yuniarti, N., Saputra, W.R., Utami, R. and Mulatsih, W. (2010). Antioxidant activity, total phenolic, and total flavaonoid of extracts and fractions of red fruit (Pandanus conoideus Lam). International Food Research Journal, 17(1), 97-106.

Shekhar, T.C. and Anju, G. (2014). Antioxidant Activity by DPPH Radical Scavenging Method of Ageratum conyzoides. American Journal of Ethnomedicine, 1 (4), 244-249.

Suresh, S. and Sisodia, S.S. (2018). Phytochemical and Pharmacological Aspects of Cucurbita moschata and Moringa oleifera. UK Journal of Pharmaceutical and Biosciences, 6(6), 45-53. https:// doi.org/10.20510/ukjpb/6/i6/179239

Vyas, S., Kachhwaha, S. and Kothari, S.L. (2015). Comparative analysis of phenolic contents and total antioxidant capacity of Moringa oleifera Lam. Pharmacognosy Journal, 7(1), 44-51. https:// doi.org/10.5530/pj.2015.7.5

Wijaya, Y.A., Widyadinata, D., Irawaty, W., Ayucitra, A., Citrus, P., Aktivitas, E. and Efek, A. (2017). Fractionation of Phenolic and Flavonoid Compounds from Kaffir Lime (Citrus hystrix) Peel Extract and
Evaluation of Antioxidant Activity. Reaktor, 17(3), 111-117. https://doi.org/10.14710/reaktor.17.3.111117

Yamin, Ruslin, Sartinah, A., Ihsan, S., Kasmawati, H., Suryani, Andriyani, R., Asma, Adjeng, A.N.T. and Arba, M. (2020). Radical scavenging assay and determination Flavonoid and Phenolic total of extract and Fractions of Raghu bark (Dracontomelon dao (Blanco) Merr). Research Journal of Pharmacy and Technology, 13(5), 2335-2339. https:// doi.org/10.5958/0974-360X.2020.00420.5

Yamin, Wahyono and Susidarti, R.A. (2010). Isolasi dan Indentifikasi Senyawa Antibakteri dari Daun Jakang (Muenhelebeckia platyclada MEISSN). Indonesia: Universitas Gadjah Mada, Thesis. [In Bahasa Indonesia]. 